\title{
Survival in the pre-senile dementia frontotemporal lobar degeneration with TDP-43 proteinopathy: effects of genetic, demographic and neuropathological variables
}

\author{
Richard A. Armstrong \\ Vision Sciences, Aston University, Birmingham, United Kingdom
}

\begin{abstract}
Factors associated with survival were studied in 84 neuropathologically documented cases of the pre-senile dementia frontotemporal dementia lobar degeneration (FTLD) with transactive response (TAR) DNA-binding protein of $43 \mathrm{kDa}$ (TDP-43) proteinopathy (FTLD-TDP). Kaplan-Meier survival analysis estimated mean survival as 7.9 years (range: 1-19 years, $S D=4.64)$. Familial and sporadic cases exhibited similar survival, including progranulin $(G R N)$ gene mutation cases. No significant differences in survival were associated with sex, disease onset, Braak disease stage, or disease subtype, but higher survival was associated with lower post-mortem brain weight. Survival was significantly reduced in cases with associated motor neuron disease (FTLD-MND) but increased with Alzheimer's disease (AD) or hippocampal sclerosis (HS) co-morbidity. Cox regression analysis suggested that reduced survival was associated with increased densities of neuronal cytoplasmic inclusions (NCI) while increased survival was associated with greater densities of enlarged neurons (EN) in the frontal and temporal lobes. The data suggest that: (1) survival in FTLD-TDP is more prolonged than typical in pre-senile dementia but shorter than some clinical subtypes such as the semantic variant of primary progressive aphasia (sVPPA), (2) MND co-morbidity predicts poor survival, and (3) NCI may develop early and EN later in the disease. The data have implications for both neuropathological characterization and subtyping of FTLD-TDP.
\end{abstract}

Key words: frontotemporal dementia lobar degeneration (FTLD), survival, Kaplan-Meier estimator.

\section{Introduction}

Studies of the life expectancy of patients with dementia are important in calculating prevalence rates, while identifying factors that influence survival is useful both in counseling patients and their families and in public health planning [14,60]. However, there have been relatively few studies of survival especially in the pre-senile dementias [36] includ- ing frontotemporal dementia (FTD), the second most common form of cortical dementia of early-onset after Alzheimer's disease (AD) [55,59]. Frontotemporal dementia is associated with a variety of clinical syndromes including FTD-motor neuron disease (FTD-MND), behavioral variant FTD (bvFTD), nonfluent variant of primary progressive aphasia (nfPPA), and the semantic variant of PPA (svPPA) [12]. 
Frontotemporal dementia is a clinical diagnosis, and pathological variants of the disease are termed frontotemporal lobar degeneration (FTLD). A specific pathological subtype of FTLD, viz., FTLD with transactive response (TAR) DNA-binding protein of $43 \mathrm{kDa}$ (TDP-43) proteinopathy (FTLD-TDP), previously called FTLD with ubiquitin-immunoreactive inclusions (FTLD-U) [38,64], is characterized by a variable neocortical and allocortical atrophy principally affecting the frontal and temporal lobes. In addition, there is neuronal loss, microvacuolation of superficial cortical laminae, and a reactive astrocytosis $[10,19]$ A variety of TDP-43-immunoreactive inclusions are present in these cases including neuronal cytoplasmic inclusions $(\mathrm{NCl})$, neuronal intranuclear inclusions (NII), dystrophic neurites (DN), and glial inclusions (GI) $[10]$.

FTLD-TDP exhibits considerable pathological heterogeneity which may affect survival [10]. First, various genetic defects have been identified, the majority being caused by mutation of the progranulin $(G R N)$ gene (FTLD-TDP-GRN) [11,13,23,46,51,61]. A less prevalent disorder, FTLD with valosin-containing protein (VCP) gene mutation [28], also has TDP-43 immunoreactive inclusions, and familial cases have also been shown to be caused by the chromosome 9 open reading frame 72 (C9ORF72) gene [39,52]. Second, FTLD is associated with various co-morbidities including MND (FTLD-MND), such cases being associated with a more localized pattern of frontal lobe atrophy [63] and with hippocampal sclerosis (HS) [1], in which significant neuronal loss occurs in the subiculum and sector CA1 of the hippocampus [35]. In addition, cases of later onset exhibit AD neuropathological change (ADNC), viz. senile plaques (SP) and neurofibrillary tangles (NFT) [10]. Third, various subtypes of FTLD-TDP have been proposed based on pathological criteria $[20,40,53]$. Using the system proposed by Cairns et al. [20]: type 1 cases are characterized by long DN in superficial cortical laminae with few or no $\mathrm{NCl}$ or $\mathrm{NII}$, type 2 by numerous $\mathrm{NCl}$ in superficial and deep cortical laminae with infrequent DN and sparse or no NII, type 3 by pathology predominantly affecting the superficial cortical laminae with numerous $\mathrm{NCl}$, DN and varying numbers of $\mathrm{NII}$, and type 4 by numerous $\mathrm{NII}$, and infrequent $\mathrm{NCl}$ and DN especially in neocortical areas [20].

Many published studies suggest that survival rates in the dementias vary considerably and may depend on numerous factors [17]. Hence, survival may depend on age at diagnosis, sex, disease subtype, and severity of progression [5]. The objective of the present study was to investigate the influence of genetics, demographic variables, co-morbidity, and neuropathology on survival, as measured by duration of dementia, in a sample of well-documented FTLD-TDP cases [10]. Kaplan-Meier survival analysis was used to determine whether survival was influenced by genetics, demographic factors, or co-morbidity, while Cox regression analysis was used to determine whether there were correlations between survival and predictor variables such as the densities of TDP-43-reactive inclusions in various brain regions $[33,48,66]$.

\section{Material and methods \\ Cases}

Eighty-four cases of FTLD-TDP (see Table I) were obtained from dementia centers in the USA and Canada: (1) Washington University School of Medicine, St. Louis, MO, USA; (2) University of California, Davis, CA, USA; (3) University of Pittsburgh, Pittsburgh, PA, USA; (4) Vancouver General Hospital, Vancouver, Canada; (5) Harvard Brain Tissue Resource Center, Belmont, MA, Emory University, Atlanta, GA, USA; (6) University of Washington, Seattle, WA, USA; (7) Columbia University, New York, NY, USA; (8) University of California, Irvine, CA, USA and (9) University of Michigan, Ann Arbor, MI, USA. All cases exhibited FTD with neuronal loss, microvacuolation in the superficial cortical laminae, and reactive astrocytosis consistent with diagnostic criteria for FTLD-TDP [19,39]. A variety of TDP-43-immunoreactive inclusions were present in these cases including $\mathrm{NCl}, \mathrm{NII}, \mathrm{DN}$, and Gl. Of the 84 cases, 39 (46\%) were familial (one or more first degree relatives affected) and of these, 16 cases (19\%) had GRN mutations $[11,13,23,46,51,61]$, one had a VCP gene mutation [28], and one case was associated with C90RF72 $[39,52]$. The genetic defects in the remaining familial cases have not been identified to date. Nine of the cases $(11 \%)$ had coexisting MND (FTLD-MND) [34,37] and seven (8\%) were identified as having associated HS (FTLD-HS). Twelve cases (14\%) were identified as having ADNC greater than expected from normal aging [44]. Braak staging was based on the density and distribution of $\beta$-amyloid $(A \beta)$ deposits and NFT $[15,16]$ and cases were also assigned to the four pathological subtypes [20]. 
Table I. Demographic details of the 84 cases of frontotemporal dementia lobar degeneration (FTLD) with TDP-43 proteinopathy (FTLD-TDP) used in the study. Data for age at death, survival, and disease onset are means with standard deviations (SD) in parentheses

\begin{tabular}{|lcccc|}
\hline Patient group & $N$ & $\begin{array}{c}\text { Death } \\
\text { (years) }\end{array}$ & $\begin{array}{c}\text { Onset } \\
\text { (years) }\end{array}$ & $\begin{array}{c}\text { Mean survival } \\
\text { (years) }\end{array}$ \\
\hline Sporadic cases & $45(22 \mathrm{M}, 23 \mathrm{~F})$ & $71.02(1.49)$ & $63.31(1.43)$ & $7.54(0.80)$ \\
\hline GRN mutation & $16(9 \mathrm{M}, 7 \mathrm{~F})$ & $70.33(2.55)$ & $61.27(2.45)$ & $7.61(0.79)$ \\
\hline Other familial cases & $23(11 \mathrm{M}, 12 \mathrm{~F})$ & $68.45(2.10)$ & $60.82(2.02)$ & $9.07(1.01)$ \\
\hline
\end{tabular}

$N$ - number of cases, GRN - progranulin, $M$ - male, $F$-female

\section{Case records}

The following data were obtained from case and post-mortem records: (1) family history, (2) the presence of MND, HS, or AD co-morbidity, (3) age at death, (4) disease duration, measured from the onset of dementia symptoms, determined by clinical assessment, and defined as cognitive dysfunction sufficiently severe to impair activities of daily living, and (5) total brain weight.

\section{Histological methods}

After death, consent of the next-of-kin was obtained for brain removal, following local Ethical Committee procedures and the 1995 Declaration of Helsinki (as modified in Edinburgh, 2000). Tissue blocks were taken from the frontal lobe at the level of the genu of the corpus callosum to study the middle frontal gyrus (MFG) and temporal lobe at the level of the lateral geniculate body to study the inferior temporal gyrus (ITG), parahippocampal gyrus (PHG), CA1/2 sectors of the hippocampus, and dentate gyrus (DG). Tissue was fixed in $10 \%$ phosphate-buffered formal saline and embedded in paraffin wax. Immunohistochemistry (IHC) was performed on 4 to $10 \mu \mathrm{m}$ sections with a rabbit polyclonal antibody that recognizes TDP-43 epitopes (dilution 1 : 1000; ProteinTech Inc., Chicago, IL). Sections were counterstained with hematoxylin.

\section{Quantitative analysis of neuropathology}

In the MFG, ITG, and PHG of each case, histological features were counted along strips of tissue (1600 to $3200 \mu \mathrm{m}$ in length) located parallel to the pia mater, using $250 \times 50 \mu \mathrm{m}$ sample fields arranged contiguously [3]. The sample fields were located in both the upper and lower cortex, the short edge of the field being orientated parallel with the pia mater and aligned with guidelines marked on the slide. Between 32 and 64 fields were used to quantify each region. In the majority of cases, the upper and lower fields quantified lesions in lamina II and part of lamina III and in laminae V/VI respectively. In the hippocampus, the features were counted in the cornu ammonis (CA) in a region extending from the prosubiculum/CA boundary to the maximum point of curvature of the pyramidal layer before it extends to join the dentate fascia via CA3 and CA4. Hence, the region sampled encompassed approximately sectors CA1 and CA2, the short dimension of the contiguous field being aligned with the alveus. Little pathology was observed to extend into CA3/4 in these cases [10]. To quantify pathology in the dentate gyrus $[38,41,64]$, the sample field was aligned with the upper edge of the granule cell layer. The $\mathrm{NCl}$ are rounded, spicular, or skein-like in shape [24,65], while the GI morphologically resemble the 'coiled bodies' reported in various tauopathies such as corticobasal degeneration (CBD), progressive supranuclear palsy (PSP), and argyrophilic grain disease (AGD). The NII are lenticular or spindle-shaped [50] and the DN characteristically long and contorted [31]. Small spherical or asymmetrical nuclei without cytoplasm but with the presence of a thicker nuclear membrane and more heterogeneous chromatin were identified as glial cells [2]. Abnormally enlarged neurons (EN) had enlarged perikarya, lacked $\mathrm{NCl}$, had a shrunken nucleus displaced to the periphery of the cell, and the maximum cell diameter was at least three times the nucleus diameter $[2,4]$. The number of discrete vacuoles greater than $5 \mu \mathrm{m}$ in diameter was also recorded in each field [9].

\section{Data analysis}

First, the survival data as a whole were tested for normality using the Kolmogorov-Smirnov and chisquare $\left(\chi^{2}\right)$ goodness of fit tests. The degree of skew 
in the data was also tested. Second, the KaplanMeier 'product limit estimator' was used to study the overall pattern of survival among the 84 cases and is the fraction of cases which survive for a certain period after disease onset. In typical applications, the cases can also be grouped according to a categorical predictor variable and the effect of the variable on survival tested. Where two groups were present, e.g.,familial/sporadic, male/female, presence/absence of co-morbidity, survival was compared using the log-rank test which determines whether the hazard ratio (HR) is significantly different from unity [5]. An assumption of this analysis is that the HR is relatively constant across time intervals ('proportionality assumption'). This assumption was tested by two methods: (1) by examining changes in the HR over time and (2) by fitting a model that includes, in addition to a fixed covariate group, a time-dependent variable. If the time-dependent covariate is not significant, then proportionality can be assumed and a model with the single fixed covariate is likely to be appropriate. Where more than two groups were present, survival was compared using the chi-square $\left(\chi^{2}\right)$ test. In addition, a life table analysis was performed to predict the life expectancy of FTLD-TDP patients at each age. Third, Cox regression was used to study the relationship between survival and vari-

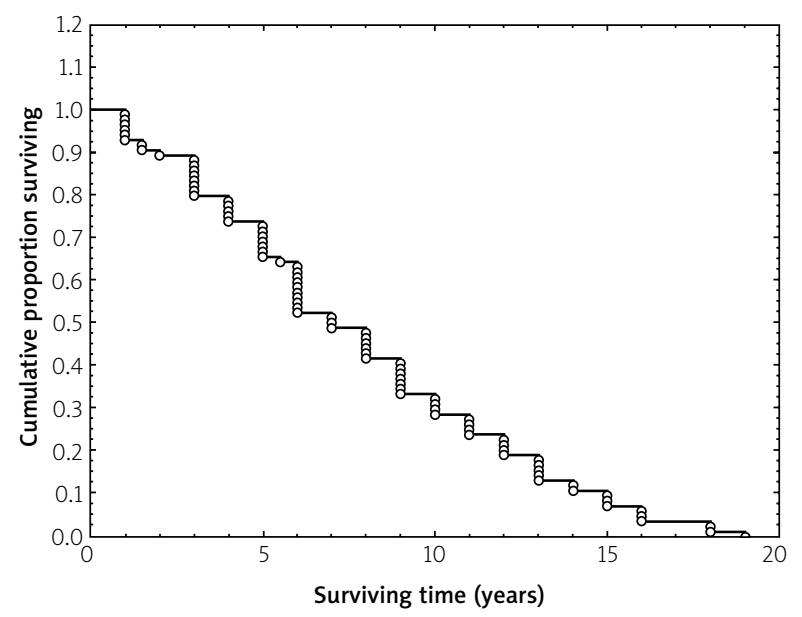

Fig. 1. Kaplan-Meier survival analysis of all 84 frontotemporal dementia lobar degeneration with transactive response (TAR) DNA-binding protein of $43 \mathrm{kDa}$ (TDP-43) proteinopathy (FTLDTDP) cases. Survival data are plotted as the proportion of individuals surviving at each time and at the upper limit of each yearly time interval. ous predictor variables. Two such groups of variables were tested: (1) demographic variables such as age at death, and disease onset, and gross neuropathological assessments such as brain weight, Braak stage and disease subtype and (2) quantitative estimates of density of histological features. In each of these analyses, variables were modeled individually and were corrected for gender and age. Statistical significance in these tests was based on $t$ and the Wald statistic [5].

\section{Results}

The distribution of the data as a whole did not deviate from normality (KS d $=0.13, p>0.05$; $\chi^{2}=9.52, \mathrm{DF}=5, p>0.05$; Skew $=0.45, \mathrm{SE}=0.26$ ). Mean disease duration of the 84 FTLD-TDP cases was 7.9 years (median: 7.0 , range: $1-19$ years, $S D=4.64$ ). The survival function for all cases is shown in Figure 1 , suggesting that $25 \%$ of cases died within four years, $50 \%$ within 6.9 years, and $75 \%$ within 10 years after onset of dementia. In addition, the data are summarized as a 'life table' (Table II), suggesting that median life expectancy was 7.58 years

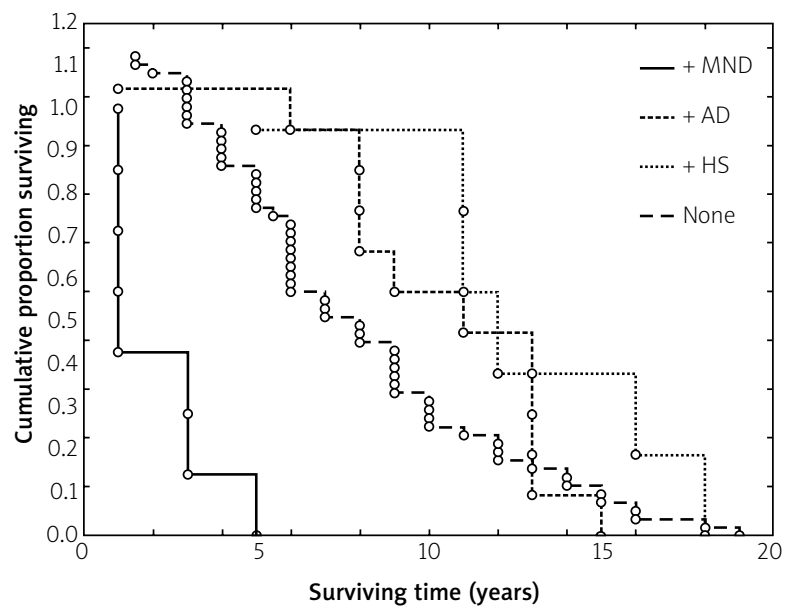

Fig. 2. Kaplan-Meier survival analysis of the data grouped into those FTLD-TDP patients with no co-morbidity (None), and those with associated Alzheimer's disease (AD) (HR $=0.51$, $\mathrm{Cl}=0.30)$, hippocampal sclerosis ( $\mathrm{HS})(\mathrm{HR}=0.35$, $\mathrm{Cl}=0.30)$, or motor neuron disease (MND) $(\mathrm{HR}=2.23, \mathrm{Cl}=0.18)$ (comparison between groups: $\left.\chi^{2}=6.83, p<0.05\right)$. Survival data are plotted as the proportion of individuals surviving at each time and at the upper limit of each yearly time interval. 
Table II. Life table for 84 frontotemporal dementia lobar degeneration with transactive response (TAR) DNA-binding protein of $43 \mathrm{kDa}$ (TDP-43) proteinopathy (FTLD-TDP) cases

\begin{tabular}{|c|c|c|c|c|c|}
\hline $\begin{array}{l}\text { Interval } \\
\text { (mid-point) }\end{array}$ & $\begin{array}{l}\text { Number } \\
\text { entering }\end{array}$ & $\begin{array}{c}\text { Number } \\
\text { dying }\end{array}$ & $\begin{array}{l}\text { Proportion } \\
\text { dying }\end{array}$ & $\begin{array}{c}\text { Hazard } \\
\text { rate }\end{array}$ & Median LE \\
\hline 0.5 & 84 & 0 & 0 & 0 & 7.58 \\
\hline 1.5 & 84 & 8 & 0.10 & 0.10 & 6.67 \\
\hline 2.5 & 76 & 1 & 0.01 & 0.01 & 6.50 \\
\hline 3.5 & 75 & 8 & 0.12 & 0.11 & 5.58 \\
\hline 4.5 & 67 & 5 & 0.07 & 0.08 & 5.21 \\
\hline 5.5 & 62 & 8 & 0.13 & 0.14 & 4.57 \\
\hline 6.5 & 54 & 10 & 0.19 & 0.20 & 4.25 \\
\hline 7.5 & 44 & 3 & 0.07 & 0.07 & 4.50 \\
\hline 8.5 & 41 & 6 & 0.15 & 0.16 & 3.87 \\
\hline 9.5 & 35 & 7 & 0.20 & 0.22 & 3.63 \\
\hline 10.5 & 28 & 4 & 0.14 & 0.15 & 3.40 \\
\hline 11.5 & 24 & 4 & 0.17 & 0.18 & 2.80 \\
\hline 12.5 & 20 & 4 & 0.20 & 0.22 & 2.50 \\
\hline 13.5 & 16 & 5 & 0.31 & 0.37 & 2.33 \\
\hline 14.5 & 11 & 2 & 0.18 & 0.20 & 2.17 \\
\hline 15.5 & 9 & 3 & 0.33 & 0.40 & 1.50 \\
\hline 16.5 & 6 & 3 & 0.50 & 0.67 & 1.00 \\
\hline 17.5 & 3 & 0 & 0.17 & 0.18 & 1.60 \\
\hline 18.5 & 3 & 2 & 0.67 & 1.00 & 0.75 \\
\hline 19 & 1 & 1 & 0.50 & - & - \\
\hline
\end{tabular}

$L E$ - life expectancy

immediately after diagnosis, 3.4 years 10 years after, and 0.75 years 18 years after diagnosis.

The effect of various categorical predictor variables on survival is shown in Table III. The data suggest no significant differences in survival between familial and sporadic cases (log rank $=0.03, p>0.05$ ) or among cases divided into sporadic, GRN mutation, and remaining familial cases $\left(\chi^{2}=1.81\right.$, DF $=2$, $p>0.05)$. In addition, there were no significant differences in survival in males and females (log rank $=0.68, p>0.05)$. However, significant effects of comorbidity on survival were evident $\left(\chi^{2}=22.70, \mathrm{DF}=3\right.$, $p<0.001)$, cases with associated MND exhibiting reduced survival compared with those without copathology $(\mathrm{HR}=2.23, \mathrm{Cl}=0.18)$ and those with associated $A D(H R=0.51, C l=0.30)$ and $H S(H R=0.51$, $\mathrm{Cl}=0.35)$ showing increased survival $\left(\chi^{2}=6.83, \mathrm{DF}=2\right.$,
Table III. Comparison of survival among various groups of cases of frontotemporal dementia lobar degeneration (FTLD) with TDP-43 proteinopathy (FTLD-TDP) using the Kaplan-Meier estimator

\begin{tabular}{|lccc|}
\hline Grouping factor & $\begin{array}{c}\text { Log-rank } \\
\text { test }\end{array}$ & $\chi^{2}$ & $p$ \\
\hline Familial/Sporadic cases & 0.03 & - & $>0.05$ \\
\hline Familial/GRN/Sporadic & - & 1.81 & $>0.05$ \\
\hline Gender & 0.68 & - & $>0.05$ \\
\hline Co-morbidity all groups & - & 22.70 & $<0.001$ \\
\hline Co-morbidity: None, MND & 2.33 & - & $<0.01$ \\
\hline Co-morbidity: None, AD, HS & - & 6.83 & $<0.05$ \\
\hline Co-morbidity: AD, HS & - & 0.80 & $>0.05$ \\
\hline
\end{tabular}

P-probability, GRN - progranulin, MND - motor neuron disease, AD - Alzheimer's disease, HS - hippocampal sclerosis 
Table IV. Analysis of the influence of demographic variables, brain weight, Braak stage, and disease subtype on survival using Cox regression $\left(\beta\right.$ - regression coefficient, SE - standard error, $p$ - probability, ${ }^{* *} p<0.01$ ). Each variable was modeled individually and adjusted for gender

\begin{tabular}{|c|c|c|c|c|c|}
\hline Variable & $\beta$ & SE & $t$ & $\begin{array}{c}\text { Wald } \\
\text { statistic }\end{array}$ & $p$ \\
\hline Patient age & -0.03 & 0.01 & 2.73 & 7.48 & $<0.01$ \\
\hline Disease onset & 0.01 & 0.01 & 1.07 & 1.14 & $>0.05$ \\
\hline Brain weight & 0.01 & 0.01 & 3.07 & 9.43 & $<0.01$ \\
\hline Braak A $\beta$ stage & -0.06 & 0.19 & 0.33 & 0.10 & $>0.05$ \\
\hline Braak tangle stage & -0.06 & 0.08 & 0.74 & 0.55 & $>0.05$ \\
\hline Disease subtype & 0.09 & 0.11 & 0.77 & 0.59 & $>0.05$ \\
\hline
\end{tabular}

Table V. Analysis of the influence of the densities of neuropathological variables ( $\mathrm{NCl}$ - neuronal cytoplasmic inclusions, GI - glial inclusions, NII - neuronal intranuclear inclusions, DN - dystrophic neurites, $\mathrm{SN}$ - surviving neurons, EN - abnormally enlarged neurons, Vac - vacuolation) on survival in various brain regions (MFG - middle frontal gyrus, ITG - inferior temporal gyrus, PHG - parahippocampal gyrus, HC CA1/2 sectors of hippocampus, DG - dentate gyrus) ( $\beta$ - regression coefficient, SE - standard error, $p$ - probability). Variables were modeled in groups for each brain region and adjusted for gender.

\begin{tabular}{|c|c|c|c|c|c|c|}
\hline Region & Histology & $\beta$ & SE & $t$ & Wald & $p$ \\
\hline \multirow[t]{7}{*}{ MFG(U) } & $\mathrm{NCl}$ & 0.60 & 0.79 & 0.74 & 0.56 & $>0.05$ \\
\hline & GI & 0.68 & 1.89 & 0.36 & 0.13 & $>0.05$ \\
\hline & NII & -0.33 & 0.83 & 0.59 & 0.35 & $>0.05$ \\
\hline & DN & -0.36 & 0.36 & 0.93 & 0.88 & $>0.05$ \\
\hline & EN & -0.16 & 1.14 & 0.32 & 0.10 & $>0.05$ \\
\hline & $N$ & -0.01 & 0.09 & 1.83 & 3.34 & $>0.05$ \\
\hline & Vac & -0.04 & 0.02 & 1.89 & 3.50 & $>0.05$ \\
\hline \multirow[t]{7}{*}{ MFG $(\mathrm{L})$} & $\mathrm{NCl}$ & 1.81 & 1.07 & 1.67 & 2.80 & $>0.05$ \\
\hline & $\mathrm{Gl}$ & -3.85 & 1.75 & 2.19 & 4.82 & $<0.05$ \\
\hline & $\mathrm{NII}$ & 0.42 & 0.76 & 0.56 & 0.31 & $>0.05$ \\
\hline & DN & 0.005 & 0.36 & 0.01 & 0.02 & $>0.05$ \\
\hline & EN & 0.81 & 1.42 & 0.57 & 0.31 & $>0.05$ \\
\hline & $\mathrm{N}$ & 0.24 & 0.10 & 2.54 & 6.45 & $<0.05$ \\
\hline & Vac & 0.05 & 0.03 & 1.91 & 3.64 & $>0.05$ \\
\hline \multirow[t]{7}{*}{$\mathrm{ITG}(\mathrm{U})$} & $\mathrm{NCl}$ & 1.46 & 0.48 & 3.56 & 12.69 & $<0.001$ \\
\hline & Gl & -3.36 & 1.48 & 2.26 & 5.12 & $<0.05$ \\
\hline & $\mathrm{NII}$ & -0.44 & 0.82 & 0.53 & 0.29 & $>0.05$ \\
\hline & DN & -0.80 & 0.25 & 2.21 & 4.88 & $<0.05$ \\
\hline & EN & -0.73 & 2.19 & 0.33 & 0.11 & $>0.05$ \\
\hline & $N$ & -0.19 & 0.07 & 2.86 & 8.21 & $<0.001$ \\
\hline & Vac & -0.03 & 0.03 & 1.15 & 1.33 & $>0.05$ \\
\hline
\end{tabular}


Table V. Cont.

\begin{tabular}{|c|c|c|c|c|c|c|}
\hline Region & Histology & $\beta$ & SE & $t$ & Wald & $p$ \\
\hline \multirow[t]{7}{*}{ ITG(L) } & $\mathrm{NCl}$ & 0.52 & 0.73 & 0.71 & 0.51 & $>0.05$ \\
\hline & Gl & -0.91 & 1.58 & 0.57 & 0.33 & $>0.05$ \\
\hline & NII & -0.14 & 0.72 & 0.20 & 0.04 & $>0.05$ \\
\hline & DN & -0.64 & 0.70 & 0.91 & 0.84 & $>0.05$ \\
\hline & EN & -1.52 & 1.09 & 1.40 & 1.95 & $>0.05$ \\
\hline & $N$ & -0.19 & 0.08 & 2.39 & 5.75 & $<0.05$ \\
\hline & Vac & 0.03 & 0.04 & 0.86 & 0.75 & $>0.05$ \\
\hline \multirow[t]{7}{*}{$\mathrm{PHG}(\mathrm{U})$} & $\mathrm{NCl}$ & 0.72 & 0.63 & 1.14 & 1.31 & $>0.05$ \\
\hline & Gl & 1.85 & 1.88 & 0.98 & 0.97 & $>0.05$ \\
\hline & NII & 0.46 & 0.88 & 052 & 0.28 & $>0.05$ \\
\hline & DN & -0.15 & 1.19 & 0.43 & 0.18 & $>0.05$ \\
\hline & EN & 1.18 & 1.19 & 0.99 & 0.99 & $>0.05$ \\
\hline & $N$ & -0.20 & 0.08 & 2.47 & 6.13 & $<0.05$ \\
\hline & Vac & -0.10 & 0.03 & 3.26 & 10.67 & $<0.001$ \\
\hline \multirow[t]{7}{*}{$\mathrm{PHG}(\mathrm{L})$} & $\mathrm{NCl}$ & -1.35 & 0.89 & 1.51 & 2.28 & $<0.05$ \\
\hline & $\mathrm{Gl}$ & 0.57 & 1.91 & 0.29 & 0.09 & $>0.05$ \\
\hline & $\mathrm{NII}$ & -1.07 & 0.74 & 1.45 & 2.10 & $>0.05$ \\
\hline & DN & -0.76 & 0.49 & 1.55 & 2.42 & $>0.05$ \\
\hline & EN & -3.17 & 1.37 & 2.31 & 5.37 & $<0.05$ \\
\hline & $\mathrm{N}$ & 0.09 & 0.09 & 0.99 & 0.98 & $>0.05$ \\
\hline & Vac & -0.76 & 0.03 & 1.92 & 3.69 & $>0.05$ \\
\hline \multirow[t]{7}{*}{$\mathrm{HC}$} & $\mathrm{NCl}$ & 3.68 & 1.38 & 2.67 & 7.11 & $<0.05$ \\
\hline & $\mathrm{Gl}$ & -0.90 & 1.97 & 0.45 & 0.21 & $>0.05$ \\
\hline & $\mathrm{NII}$ & -0.27 & 0.60 & 0.44 & 0.20 & $>0.05$ \\
\hline & DN & -0.05 & 0.70 & 0.06 & 0.01 & $>0.05$ \\
\hline & EN & -1.83 & 1.04 & 1.77 & 3.11 & $>0.05$ \\
\hline & $N$ & -0.06 & 0.11 & 0.55 & 0.31 & $>0.05$ \\
\hline & Vac & -0.09 & 0.03 & 0.69 & 0.03 & $>0.05$ \\
\hline \multirow[t]{6}{*}{ DG } & $\mathrm{NCl}$ & 0.09 & 0.33 & 0.29 & 0.08 & $>0.05$ \\
\hline & $\mathrm{NII}$ & -1.06 & 1.62 & 0.65 & 0.43 & $>0.05$ \\
\hline & DN & -2.53 & 4.32 & 0.59 & 0.34 & $>0.05$ \\
\hline & EN & -2.95 & 15.94 & 0.18 & 0.03 & $>0.05$ \\
\hline & $\mathrm{N}$ & -0.12 & 0.05 & 2.31 & 5.32 & $<0.05$ \\
\hline & Vac & -0.07 & 0.05 & 0.59 & 1.67 & $>0.05$ \\
\hline
\end{tabular}


$p<0.05)$. The HR for MND and HS were relatively constant across time intervals and the time-dependent covariates non-significant, suggesting that the proportionality assumption was valid. However, HR for $A D$ varied between time intervals, and the timedependent covariate was significant $(t=2.23, p<$ $0.05)$, thus violating the assumption of proportionality.

The results of the Cox regression analysis, corrected for gender, which included the demographic variables, brain weight, Braak staging, and pathological disease subtype, are shown in Table IV. The data suggest: (1) a relationship between patient age and survival ( $t=8.81, p<0.01)$, better survival being associated with a later age at death, (2) no significant association between survival and disease onset ( $t=0.79, p>0.05$ ), (3) a significant relationship with brain weight $(t=3.07, p<0.01)$, lower brain weight being associated with increased survival, and (3) no significant association between survival and Braak stages (A $: t=0.33, p>0.05$; NFT: $t=0.75$, $p>0.05)$, or disease subtype $(t=0.82, p>0.05)$.

The results of the Cox regression analysis, corrected for gender, applied to the quantitative neuropathological variables measured in each brain region, are shown in Table V. Some histological features were associated with increased survival, including $\mathrm{Gl}$ in the MFG $(t=2.19, p<0.05)$, DN in the ITG $(t=2.21, p<0.05)$, EN in the PHG $(t=2.31, p<0.05)$ neurons in the MFG $(t=2.54, p<0.05)$ and ITG $(t=2.86, p<0.001)$, and vacuoles in the PHG $(t=3.26$, $p<0.001)$. By contrast, density of $\mathrm{NCl}$ was associated with poorer survival in the ITG $(t=3.56, p<0.001)$ and $\mathrm{HC}(t=2.67, p<0.05)$. A similar pattern of relationships was seen when the analysis was corrected for patient age. Only correlations between $\mathrm{NCl}$ in the ITG and EN in the PHG remained significant in these analyses after Bonferroni correction.

\section{Discussion}

Mean survival of the 84 FTLD-TDP cases was 7.9 years, similar to the 7.1 years recorded in a recent study of 102 AD cases [5], but longer than the 5.2 years and 6.5 years in AD estimated by Doody et al. [26] and Feldman et al. [27] respectively. Mean survival was also greater than the 6.08 years reported for a large sample of pre-senile dementia cases in the north of England, UK, but which comprised largely $A D$ and vascular dementia (VD) [36]. Survival was increased compared with that reported for a specif- ic group of $A D$ cases, which had vascular disease co-morbidity, in which mean survival was less than five years [27]. This difference probably reflects the relative ages of the cases, vascular disease co-morbidity being less of a factor in pre-senile dementia. Median survival of the group (7 years), however, was similar to that of 61 pathologically confirmed FTLD patients [32]. Survival was reduced compared with a specific clinical subtype of FTLD, viz. SVPPA, in which $50 \%$ of patients survived more than 12.8 years [33].

Two distinct subtypes of dementia progression have been identified, especially in $A D[47,54,58]$, cases having either a very short (median survival 10 months) or a significantly longer survival and which may reflect education level $[18,21]$. Short survival cases were also evident in the present sample of FTLD-TDP, nine cases surviving for two years or less. A multiple discriminant analysis (MDA) [6] which compared these cases with the remaining FTLD-TDP cases suggested that reduced survival was not associated with different ages at death, disease onset, brain weight at post-mortem, difference in quantitative neuropathology, or co-morbidity.

No significant difference in survival was observed between males and females with FTLD-TDP, contrasting with some studies which show poorer survival in males with dementia $[21,26,29]$. In addition, the data suggested that survival was similar in familial and sporadic FTLD-TDP. This result contrasts with AD in which familial cases in general and cases specifically linked to presenilin 1 (PSEN1) mutation exhibited increased survival [5].

The data suggest that the presence of co-morbidity had a significant effect on survival, associated MND significantly shortening the lifespan. This result is similar to that previously reported for FTDMND, which exhibited substantially reduced survival (median survival 3 years) [33]. Similarly in AD, the presence of at least one co-morbidity decreased survival $[5,67]$ and the presence of combined co-morbidity and functional disability was an important predictor of lower survival [66]. In FTLD-TDP, however, the presence of associated $A D$ or HS increased survival, suggesting possible synergistic interactions between competing pathologies. Consistent with this suggestion, Hodges et al. [32] found that the presence of tau pathology in FTLD improved prognosis (median survival 9.07). However, caution is necessary in interpreting these results as, first, HR for 
$A D$ varied between time intervals and the time-dependent covariate was significant $(t=2.23, p<0.05)$, thus violating the assumption of proportionality, and, second, numbers of patients were small. Bowen et al. [14] also found a strong association between decreased survival in $A D$ and cardiovascular disease (CVD), regarded as a significant determinant of progression to dementia. No effect of CVD or hypertension on survival, however, has been observed in other studies of AD [62] or in Down's syndrome (DS) patients [22], who frequently develop AD-type pathology $[42,43,45]$. Accurate quantitative data on CVD load, e.g., lacunar infarcts, micro-infarcts, and atherosclerosis of large vessels, were not available for many of the FTLD-TDP cases studied, but available data from some cases suggested that CVD load was significantly lower than in AD [5].

Whether brain weight significantly changes over the course of dementia has been controversial [5]. There are limitations in studying this complex variable post-mortem as many factors can influence brain weight, including body height and weight and the presence of systemic disease such as osteoporosis [5]. In the present study, lower brain weights were associated with better survival consistent with a gradual loss of brain volume in FTLD-TDP with disease progression. By contrast, in one study of $A D$, poorer survival was associated with lower gray matter volume, and smaller volume reductions in brain predicted better survival [56].

Cox regression analysis incorporating Bonferroni correction suggested that the density of $\mathrm{NCl}$ was positively associated with decreased survival in the ITG, suggesting either that abundant $\mathrm{NCl}$ could shorten survival times or that $\mathrm{NCl}$ could be characteristic of the early stages of the disease, being lost as the disease progresses. By contrast, the density of EN in the PHG was negatively associated with decreased survival, suggesting either that EN developed later in the disease or they could represent the earliest affected regions exposed to accumulating pathology over time. Studies suggest that pathological proteins in various neurodegenerative disorders may spread through the brain via anatomical connections $[7,30,57]$. In AD, for example, this spread frequently occurs from an origin in the medial temporal lobe to the cortical association areas and hippocampus, and then to the primary sensory areas $[8,25,49]$. Pathogenic TDP-43 may also exhibit this property, and therefore changes in density with duration in specif- ic areas could reflect this spread. That the density of a 'signature' pathological change, viz., $\mathrm{NCl}$, may vary with degree of survival has implications for both the neuropathological characterization and subtyping of FTLD-TDP, which rely on the relative density and distribution of TDP-43-reactive inclusions [20].

In conclusion, factors associated with survival were studied in 84 cases of pre-senile dementia frontotemporal dementia lobar degeneration (FTLD) with transactive response (TAR) DNA-binding protein of $43 \mathrm{kDa}$ (TDP-43) proteinopathy (FTLD-TDP). The data suggested that survival in FTLD-TDP was greater than typical for the pre-senile dementias but shorter than some clinical subtypes such as SD. In addition, MND co-morbidity is a predictor of shorter survival times. There are also changes in the density of some neuropathological changes with survival, and hence the data may have implications for both diagnosis and subtyping of FTLD-TDP.

\section{Acknowledgments}

I thank the following for making tissue sections available for this study: Knight Alzheimer's Disease Research Center, Washington University School of Medicine, St. Louis, MO, USA, William Ellis (Department of Pathology, University of California, Davis, Sacramento, CA, USA), Ronald L. Hamilton (Department of Pathology, University of Pittsburgh, Pittsburgh, PA, USA), Ian R. A. Mackenzie (Department of Pathology, Vancouver General Hospital, Vancouver, Canada), E. Tessa Hedley-Whyte (Massachusetts General Hospital and Harvard Brain Tissue Resource Center, Belmont, MA, USA), Marla Gearing (Center for Neurodegenerative Disease, Emory University, Atlanta, GA, USA).

\section{Disclosure}

Author reports no conflict of interest.

\section{References}

1. Amandor-Ortiz C, Lin WL, Ahmed Z, Personett D, Davies P, Duara R, Graff-Radford NR, Hutton ML, Dickson DW. TDP-43 immunoreactivity in hippocampal sclerosis and Alzheimer's disease. Ann Neurol 2007; 61: 435-445.

2. Armstrong RA. Correlations between the morphology of diffuse and primitive $\beta$-amyloid $(A \beta)$ deposits and the frequency of associated cells in Down's syndrome. Neuropath Appl Neurobiol 1996; 22: 527-530. 
3. Armstrong RA. Quantifying the pathology of neurodegenerative disorders: quantitative measurements, sampling strategies and data analysis. Histopathology 2003; 42: 521-529.

4. Armstrong RA. A quantitative study of abnormally enlarged neurons in cognitively normal brain and neurodegenerative disease. Clin Neuropathol 2013; 32: 128-134.

5. Armstrong RA. Factors determining disease duration in Alz heimer's disease: A postmortem study of 103 cases using the Kaplan-Meir estimator and Cox regression. Biomed Intern 2014; Article ID: 623487.

6. Armstrong RA, Hilton AC. Statistical analysis in microbiology: Statnotes. Wiley-Blackwell, Hoboken, New Jersey 2011.

7. Armstrong RA, Cairns NJ. Different molecular pathologies result in similar spatial patterns of cellular inclusions in neurodegenerative disease: a comparative study of eight disorders. J Neural Transm 2012; 119: 1551-1560.

8. Armstrong RA, Myers D, Smith CUM. Alzheimer's disease: size class frequency distributions of senile plaques: do they indicate when a brain tissue was affected? Neurosci Lett 1991; 127: 223-226.

9. Armstrong RA, Ironside J, Lantos PL, Cairns NJ. A quantitative study of the pathological changes in the cerebellum of 15 cases of variant Creutzfeldt-Jakob disease. Neuropathol Appl Neurobio 2009; 35: 36-45.

10. Armstrong RA, Ellis W, Hamilton RL, Mackenzie IRA, Hedreen J, Gearing M, Montine T, Vonsattel J-P, Head E, Lieberman AP, Cairns NJ. Neuropathological heterogeneity in frontotemporal lobar degeneration with TDP-43 proteinopathy: a quantitative study of 94 cases using principal components analysis. J Neural Transm 2010; 117: 227-239.

11. Baker M, Mackenzie IR, Pickering-Brown SM, Gass J, Rademakers R, Lindholm C, Snowden J, Adamson J, Sadovnick AD, Rollinson S, Cannon A, Dwosh E, Neary D, Melquist S, Richardson A, Dickson D, Berger Z, Eriksen J, Robinson T, Zehr C, Dickey CA, Crook R, McGowan E, Mann D, Boeve B, Feldman H, Hutton M. Mutations in progranulin cause tau-negative frontotemporal dementia linked to chromosome 17. Nature 2006; 442: 916-919.

12. Bang J, Spina S, Miller BL. Frontotemporal dementia. Lancet 2015; 386: 1672-1682.

13. Behrens MI, Mukherjee O, Tu PH, Liscic RM, Grinberg LT, Carter D, Paulsmeyer K, Taylor-Reinwald L, Gitcho M, Norton JB, Chakraverty S, Goate AM, Morris JC, Cairns NJ. Neuropathologic heterogeneity in HDDD1: a familial frontotemporal lobar degeneration with ubiquitin-positive inclusions and progranulin mutation. Alz Dis Assoc Disord 2007; 21: 1-7.

14. Bowen JD, Malter AD, Shepperd L, Kukull WA, McCormick WC, Teri L, Larson EB. Predictors of mortality in patients diagnosed with probable Alzheimer's disease. Neurology 1996; 47: 433-439.

15. Braak H, Braak E. Neuropathological staging of Alzheimer-related changes. Acta Neuropathol 1991; 82: 239-259.

16. Braak H, Alafuzoff I, Arzberger T, Kretzschmar H, Del Tredici K. Staging of Alzheimer disease-associated neurofibrillary pathology using paraffin sections and immunocytochemistry. Acta Neuropathol 2006; 112: 389-404.

17. Brodaty H, K. Seeher K, Gibson L. Dementia time to death: a systematic literature review on survival time and years of life lost in people with dementia. Intern Psychogeriatr 2012; 24 1034-1045.
18. Bruandet A, Richard F, Bombois S, Maurage CA, Masse I, Amouyel P, Pasquier F. Cognitive decline and survival in Alzheimer's disease according to education level. Dement Cog Geriatr 2008; 25: 74-80.

19. Cairns NJ, Neumann M, Bigio EH, Holm IE, Troost D, Hatanpaa KJ, Foong C, White CL III, Schneider JA, Kretzschmar HA, Carter D, Taylor-Reinwald L, Paulsmeyer K, Strider J, Gitcho M, Goate AM, Morris JC, Mishra M, Kwong LK, Steiber A, Xu Y, Forman MS, Trojanowski JQ, Lee VMY, Mackenzie IRA. TDP-43 familial and sporadic frontotemporal lobar degeneration with ubiquitin inclusions. Am J Pathol 2007; 171: 227-240.

20. Cairns NJ, Bigio EH, Mackenzie IRA, Neumann M, Lee VMY, Hatanpaa KJ, White CL, Schneider JA, Grinberg LT, Halliday G, Duyckaerts C, Lowe JS, Holm IE, Tolnay M, Okamoto K, Yokoo H, Murayama S, Woulfe J, Munoz DG, Dickson DW, Ince PG, Trojanowski JQ, Mann DMA. Neuropathologic diagnostic and nosological criteria for frontotemporal lobar degeneration: consensus of the Consortium for Frontotemporal Lobar Degeneration. Acta Neuropathol 2007; 114: 5-22.

21. Claus JJ, van Gool WA, Teunisse S, Walstra GJM, Kwa VIH, Hijdra A, Verbeeten B, Koelman JHTM, Bour LJ, De Visser BWO. Predicting survival in patients with early Alzheimer's disease. Dem Cogn Geriatr 1998; 9: 284-293.

22. Coppus AMW, Evenhuis HM, Verberne GJ, Visser FE, Oostra BA, Eikelenboom P, van Gool WA, Janssens ACJW, van Duijn CM. Survival in elderly persons with Down's syndrome. Am Geriatr Soc 2008; 6: 2311-2316.

23. Cruts M, Gijselink I, van der ZJ, Engelborgs S, Wils H, Pirici D, Radamakers R, Vandenberghe R, Dermaut B, Martin JJ, van Duijn C, Peeters K, Sciot R, Santens P, De pooter T, Mattheijssens M, van den BM, Cuijt I, Vennekens K, De Deyn PP, Kumar-Singh S, Van Broeckhoven C. Null mutations in progranulin cause ubiquitin-positive frontotemporal dementia linked to chromosome 17q21. Nature 2006; 442: 920-924.

24. Davidson Y, Kelley T, Mackenzie IRA, Pickering Brown S, Du Plessis D, Neary D, Snowden JS, Mann DMA. Ubiquinated pathological lesions in frontotemporal lobar degeneration contain TAR DNA-binding protein, TDP-43. Acta Neuropathol 2007; 113: 521533.

25. De Lacoste M, White CL. The role of cortical connectivity in Alzheimer's disease pathogenesis: a review and model system. Neurobiol Aging 1993; 14: 1-16.

26. Doody R, Pavlik V, Massman P, Kenan M, Yeh S, Powell S, Cooke N, Dyer C, demirovic J, waring S, Chan WY. Changing patient characteristics and survival experience in an Alzheimer's center patient cohort. Dem Cogn Geriatr 2005; 20: 198-208.

27. Feldman HH, Pirttila T, Dartigues JF, Everitt B, van Baelen B, Brashear HR, Berlin JA, Battisti WP, Kavanagh S. Analysis of mortality risk in patients with dementia treated with galantamine. Acta Neurol Scand 2009; 119: 22-31.

28. Forman MS, Mackenzie IR, Cairns NJ, Swanson E, Boyer PJ, Drachman DA, Jhaveri BS, Karlawish JH, Pestrvik A, Smith TN, Tu PH, Watts GDJ, Markesbery WR, Smith CD, Kimonis VE. Novel ubiquitin neuropathology in frontotemporal dementia with valosin-containing protein gene mutations. J Neuropathol Exp Neurol 2006; 65: 571-581. 
29. Gambassi G, Lapane KL, Landi F, Sgaderi A, Mor V, Bernabel R. Sex differences in the relation between co-morbidity and mortality of patients with Alzheimer's disease. Neurology 1999; 53 508-516.

30. Goedert M, Clavaguera F, Tolnay M. The propagation of prionlike protein inclusions in neurodegenerative diseases. Trends Neurosci 2010; 33: 317-325.

31. Hatanpaa KJ, Bigio EH, Cairns NJ, Womack KB, Weintraub S, Morris JC, Foong C, Xiao GH, Hladik C, Mantanona TY, White CL. TAR DNA-binding protein 43 immunohistochemistry reveals extensive neuritic pathology in FTLD-U: A Midwest-Southwest Consortium for FTLD-U study. I Neuropathol Exp Neurol 2008; 67: 271-279.

32. Hodges JR, Davies R, Xuereb J, Kril J, Halliday G. Survival in frontotemporal dementia. Neurology 2003; 61: 349-354.

33. Hodges JR, Mitchell J, Dawson K, Spillantini MG, Xuereb JH, McMonagle P, Nestor PJ, Patterson K. Semantic dementia: demography, familial factors and survival in a consecutive series of 100 cases. Brain 2010; 133: 300-306.

34. Josephs KA, Knopman DS, Whitwell JL, Boeve BF, Parisi JE, Petersen RC, Dickson DW. Survival in the two variants of tau negative FTLD: FTLD-U versus FTLD-MND. Neurology 2005; 65: 645-647.

35. Josephs KA, Whitwell JL, Jack CR, Parisi JE, Dickson DW. Frontotemporal lobar degeneration without lobar atrophy. Arch Neurol 2006; 63: 1632-1638.

36. Kay DWK, Forster DP, Newens AJ. Long-term survival, place of death, and death certification in clinically diagnosed pre-senile dementia in northern England: follow-up after 8-12 years. Brit J Psychiatr 2000; 177: 156-162.

37. Kersaitis C, Holliday GM, Xuereb JH, Pamphlett R, Bak TH, Hodges JR, Kril JJ. Ubiquitin-positive inclusions and progression of pathology in FTD and MND identifies a group with mainly early pathology. Neuropathol Appl Neurobiol 2006; 32: 83-91.

38. Kovari E, Gold G, Giannakopoulos P, Bouras C. Cortical ubiquitin positive inclusions in frontotemporal dementia without motor neuron disease: a quantitative immunocytochemical study. Acta Neuropathol 2004; 108: 207-212.

39. Luty AA, Kwok JBJ, Thompson EM, Blumsbergs P, Brooks WS, Loy CT, Dobson-Stone C, Panegyres PK, Hecker J, Nicholson GA, Halliday GM, Schofield PR. Pedigree with frontotemporal lobar degeneration-motor neuron disease and Tar DNA binding protein-43 positive neuropathology: genetic linkage to chromosome 9. BMC Neurology 2008; 8: 32.

40. Mackenzie IR, Baborie A, Pickering-Brown S, Du Plessis D, Jaros E, Perry RH, Neary D, Snowden JS, Mann DMA. Heterogeneity of ubiquitin pathology in frontotemporal lobar degeneration: classification and relation to clinical phenotype. Acta Neuropathol 2006; 112: 539-549.

41. Mackenzie IRA, Baker M, Pickering-Brown S, Hsinng GYR, Lindholm C, Dwosh E, Cannon A, Rademakers R, Hutton M, Feldman $\mathrm{HH}$. The neuropathology of frontotemporal lobar degeneration caused by mutations in the progranulin gene. Brain 2006; 129: 3081-3090.

42. Mann DMA, Esiri MM. The pattern of acquisition of plaques and tangles in the brains of patients under 50 years of age with Down's syndrome. J Neurol Sci 1989; 89: 169-179.
43. Mann DMA, Younis N, Jones D, Stoddart RW. The time course of the pathological events in Down's syndrome with particular reference to the involvement of microglial cells and deposits of $\beta /$ A4. Neurodegeneration 1992; 1: 201-215.

44. Mirra SS, Heyman A, McKeel D, Sumi SM, Crain BJ, Brownlee LM, Vogel FS, Hughes JP, van Belle G, Berg $L$ et al. The consortium to establish a registry for Alzheimer's disease (CERAD). II. Standardisation of the neuropathologic assessment of Alzheimer's disease. Neurology 1991; 41: 479-486.

45. Motte J, Williams RS. Age-related changes in the density and morphology of plaques and neurofibrillary tangles in Down syndrome brain. Acta Neuropathol 1989; 77: 535-546.

46. Mukherjee O, Pastor P, Cairns NJ, Chakraaverty S, Kauwe JSK, Shears S, Behrens MI, Budde J, Hinrichs AL, Norton J, Levitch D, Taylor-Reinwald L, Gitcho M, Tu PH, Grinberg LT, Liscic RM, Armendariz J, Morris JC, Goate AM. HDDD2 is a familial frontotemporal lobar degeneration with ubiquitin-positive tau-negative inclusions caused by a missense mutation in the signal peptide of progranulin. Ann Neurol 2006; 60: 314-322.

47. Musicco M, Salamone G, Caltagirone C, Cravello L, Fadda L, Lupio F, Mosti S, Perri R, Palmer K. Neuropsychological predictors of rapidly progressing patients with Alzheimer's disease. Dem Cogn Geriatr 2010; 30: 219-228.

48. Nitrini R, Caramelli P, Herrera E, de Castro I, Bahia VS, Anghinah R, Caixeta LF, Radanovic M, Charchat-Fichman H, Porto CS, Carthery MT, Hartmann APJ. Huang N, Smid J, Lima EP, Takahashi DY, Takada LT. Mortality from dementia in a community dwelling Brazilian population. Int J Geriatr Psych 2005; 20: 247 253.

49. Pearson RCA, Esiri MM, Hiorns RW, Wilcock GK, Powell TPS. Anatomical correlates of the distribution of the pathological changes in the neocortex in Alzheimer's disease. Proc Natl Acad Sci U S A 1985; 82: 4531-4534.

50. Pirici D, Vandenberghe R, Rademakers R, Dermant B, Cruts $M$, Vennekens K, Cuijt I, Lubke U, Centerick C, Martin JJ, Van Broeckhoven C, Kumar-Singh S. Characterization of ubiquinated intraneuronal inclusions in a novel Belgian frontotemporal lobar degeneration family. J Neuropath Exp Neurol 2006; 65: 289-301.

51. Rademakers R, Hutton M. The genetics of frontotemporal lobar degeneration. Curr Neurol Neurosci Rep 2007; 7: 434-442.

52. Renton AE, Majounie E, Waite A, Simón-Sánchez J, Rollinson S, Gibbs JR, Schymick JC, Laaksovirta H, van Swieten JC, Myllykangas L, Kalimo H, Paetou A, Abramzon Y, Remes AM, Kaganovitch A, Scholz SW, Duckworth J, Ding J, Harmer DW, Hernandez DG, Johnson JO, Mok K, Ryten M, Trabzuni D, Guerreiro RJ, Orrell RW, Neal J, Murray A, Pearson J, Jansen IE, Sondervan D, Seelaar H, Blake D, Young K, Halliwell N, Callister JB, Toulson G, Ricahrdson A, Gerhard A, Snowden J, Mann D, Neary D, Nalls MA, Peuralinna T, Jansson L, Isoviita VM, Kalvorinne AL, Hölttä-Vuori M, Ikonen E, Sulkava R, Benatar M, Wuu J, chio A, Restagno G, Borghero G, Sabatelli M, The ITALSGEN Consortium, Heckerman D, Rogaeva E, Zinman L, Rothstein JD, Sendtner M, Drepper C, Eichler EE, Alkan C, Abdullaev Z, Pack SD, Dutra A, Pak E, Hardy J, Singleton A, Williams NM, Heutink P, Pickering-Brown S, Morris HR, Tienari PJ, Traynor BJ. A hexanucleotide repeat expansion in C9ORF72 is 
the cause of chromosome 9p21-linked ALS-FTD. Neuron 2011; 72: 257-268.

53. Sampathu DM, Neumann M, Kwong LK, Chou TT, Micsenyi M Truax A, Bruce J, Grossman M, Trojanowski JQ, Lee VM. Pathological heterogeneity of frontotemporal lobar degeneration with ubiquitin-positive inclusions delineated by ubiquitin immonohistochemistry and novel monoclonal antibodies. Am J Pathol 2006; 189: 1343-1352.

54. Schmidt C, Haik S, Satoh K, Rabano A, Martinez-Martin P, Roeber S, Brandel JP, de Pedro-Cuesta J, Laplanche JL, Kretzschmar H, Zerr I. Rapidly progressive Alzheimer's disease: a multicenter update. J Alz Dis 2010; 30: 751-756.

55. Snowden J, Neary D, Mann D. Frontotemporal lobar degeneration: clinical and pathological relationships. Acta Neuropatho 2007; 114: 31-38.

56. Staff RT, Murray AD, Ahearn T, Salarirad S, MOwat D, Starr JM Deary IJ, Lemmon $\mathrm{H}$, Whalley LJ. Brain volume and survival from age 78 to 85: the contribution of Alzheimer-type magnetic resonance imaging findings. J Am Geriatr 2010; 58: 688-695.

57. Steiner JA, Angot E, Brunden P. A deadly spread: cellular mechanisms of $\alpha$-synuclein transfer. Cell Death Differ 2011; 18: 1425 1433.

58. Thalhauser CJ, Komarova NL. Alzheimer's disease: rapid and slow progression. J Roy Soc 2012; 9: 119-126.

59. Tolnay M, Probst A. Frontotemporal lobar degeneration - tau as a pied piper? Neurogenetics 2002; 4: 63-75.

60. Ueki A, Shinjo H, Shimode H, Nakajima T, Morita Y. Factors associated with mortality in patients with early-onset Alzheimer's disease: a five year longitudinal study. Int J Geriatr Psych 2001; 16: 810-815.

61. Van Deerlin VM, Wood EM, Moore P, Yuan W, Forman MS Clark CM, Neumann M, Kwong LK, Trojanowski JQ, Lee VMY, Grossman M. Clinical, genetic and pathologic characteristics of patients with frontotemporal dementia and progranulin mutation. Arch Neurol 2007; 64: 1148-1153.

62. Weiner MF, Risser RC. Effect of educational attainment on survival in Alzheimer's disease. Alzheim Rep 1998; 1: 369-374.

63. Whitwell JL, Jack CR, Serijeni ML, Josephs KA. Patterns of atrophy in pathologically confirmed FTLD with or without motor neuron degeneration. Neurology 2006; 66: 102-104.

64. Woulfe J, Kertesz A, Munoz DG. Frontotemporal dementia with ubiquinated cytoplasmic and intranuclear inclusions. Acta Neuropathol 2001; 102: 94-102.

65. Yaguchi M, Fujita Y, Amari M, Takatama M, Al-Sarraj S, Leigh PN, Okamoto K. Morphological differences of intraneural ubiquitin positive inclusions in the dentate gyrus and parahippocampal gyrus of motor neuron disease with dementia. Neuropathology 2004; 24: 296-301.

66. Zekry D, Herrmann FR, C.E. Graf CE, Gianelli S, Michel JP, Gold G, Krause $\mathrm{KH}$. High levels of co-morbidity and disability cancel out the dementia effect in predictions of long-term mortality after discharge in the very old. Dem Cogn Geriatr 2011; 32: 103-110.

67. Zhou B, Zhao QH, Teramukai S, Ding D, Guo QH, Fukushimna M. Executive function predicts survival in Alzheimer's disease. J Alz Dis 2010; 22: 673-682. 